\title{
Temporal Trends in Nitrogen Concentrations and Losses from Agricultural Monitoring Sites in Latvia
}

\author{
Ieva SIKSNANE ${ }^{1 *}$, Ainis LAGZDINS ${ }^{2}$
}

\section{${ }^{1,2}$ Department of Environmental Engineering and Water Management, Faculty of Environment and Civil Engineering, Latvia University of Life Sciences and Technologies, Akademija street 19, Jelgava, Latvia}

\begin{abstract}
Water quality in small agricultural catchments is affected by anthropogenic (crops, field management operations, fertilizer application) and natural (soil texture, topography, meteorological and hydrological conditions) factors. It is important to estimate long-term (1995-2018) trends of nitrogen losses from small agricultural catchments and subsurface drainage fields to surface water bodies in order to evaluate the impacts of anthropogenic and natural factors and to cover management needs such as implementation of national legislation and the $E U$ directives. The content of the Common Agricultural Policy is currently under development, therefore, there is a need to consider existing monitoring results to address water quality goals within the next planning period. This study examines temporal trends in water discharge, total nitrogen (TN) and nitrate-nitrogen $\left(\mathrm{NO}_{3}-\mathrm{N}\right)$ concentrations and losses from three agricultural runoff monitoring sites in Latvia including Berze, Mellupite, and Vienziemite. The yearly data series of $\mathrm{TN}$ and $\mathrm{NO}_{3}-\mathrm{N}$ concentrations and loss were tested for statistical trends using the Mann-Kendall test. The study results show high variations in $\mathrm{TN}$ and $\mathrm{NO}_{3}-\mathrm{N}$ concentrations and losses among monitoring sites both in subsurface drainage field and small catchment scale. For $\mathrm{TN}$ and $\mathrm{NO}_{3}-\mathrm{N}$ losses five out of six monitoring sites showed an upward trend, while for $T N$ concentrations three out of six monitoring sites and $\mathrm{NO}_{3}-\mathrm{N}$ four out of six monitoring sites showed an upward trend. The results of this study indicate that the upward trends in $\mathrm{TN}$ losses are affected by hydrological conditions at the study sites.
\end{abstract}

Keywords - Agricultural land; concentrations; losses; nitrogen; runoff; small catchments; subsurface drainage; temporal trends

\section{INTRODUCTION}

According to the HELCOM Baltic Sea Action Plan and the EU Nitrates directive one of the main environmental issues in the Baltic Sea region is water pollution with nutrients - nitrogen and phosphorus [1], [2]. Nitrogen has been identified as a major source for deteriorated water quality in many European countries including the Baltic Sea area [1], [3]. The major source of nutrient inputs to the Baltic Sea is agriculture contributing to over 70-90\% of nitrogen inputs to the sea [1], [4].

The loss of nitrogen including total nitrogen and nitrate-nitrogen from agricultural soils depends on the amount and intensity of water passing through the soil. Artificial removal of water from agricultural lands by agricultural drainage leads to external nutrient inputs causing eutrophication in downstream water bodies. Earlier study shows that there is an increasing

* Corresponding author.

E-mail address: ieva.siksnaane@gmail.com 
trend in fertilizer application - represented by a moderately close, positive, linear relationship between total fertilizer application and sown area indicating the intensification of production [5].

To protect water quality by preventing pollution of groundwater and surface water caused by nitrates from agricultural sources, application rates of nitrogen for agricultural crops $n$ are limited by national and international legislation. The environmental aspects in Latvian legislation are in line with the EU Nitrates Directive and Water Framework Directive for the purpose to reduce the inputs of nutrients to the Baltic Sea [2], [3].

The aim of this study was to evaluate trends in total nitrogen (TN) and nitrate-nitrogen $\left(\mathrm{NO}_{3}-\mathrm{N}\right)$ concentrations and losses in three agricultural runoff monitoring sites by using longterm data and statistical trend analysis.

\section{STUdY AREA AND DATA}

This study is based on the water quantity and quality monitoring data obtained at three agricultural runoff monitoring sites situated in different regions in Latvia including Berze, Mellupite, and Vienziemite. The long-term data were acquired by the Department of Environmental Engineering and Water Management of Latvia University of Life Sciences and Technologies and the State Limited Liability Company "Latvian Environment, Geology and Meteorology Centre". The Berze study site is located within the Nitrate Vulnerable Zones designated according to the EU Nitrates directive [2], in the central region of Latvia $\left(56^{\circ} 42^{\prime} 67.57^{\prime \prime} \mathrm{N}, 23^{\circ} 22^{\prime} 78.82^{\prime \prime} \mathrm{E}\right)$. The Mellupite study site is located in the western part of Latvia $\left(56^{\circ} 29^{\prime} 68.64^{\prime \prime} \mathrm{N}, 22^{\circ} 13^{\prime} 67.13^{\prime \prime} \mathrm{E}\right)$, while the Vienziemite site is located in the northeast part of Latvia $\left(57^{\circ} 06^{\prime} 35.44^{\prime \prime} \mathrm{N}, 25^{\circ} 55^{\prime} 41.55^{\prime \prime}\right.$ E) (Fig. 1).

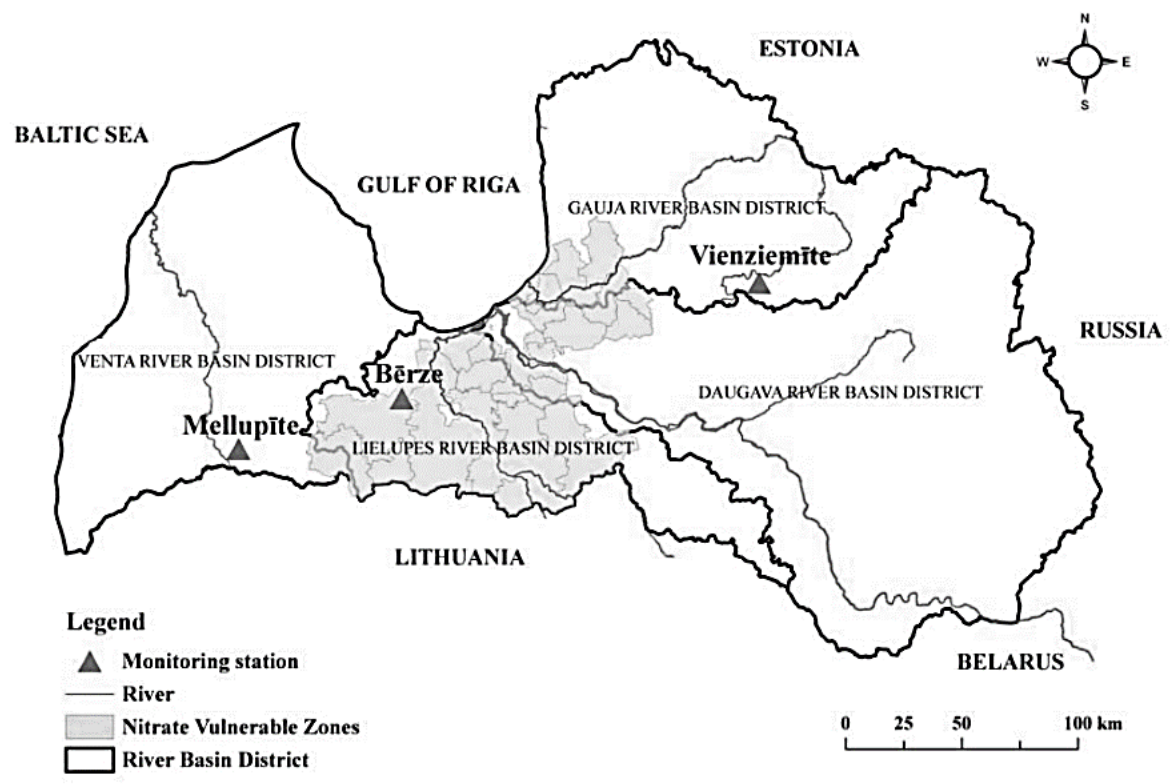

Fig. 1. Location of the study (monitoring) sites at Berze, Mellupite and Vienziemite [6]. 
The water discharge data presented in this study were obtained at subsurface drainage field and small catchment scale. Triangular weirs and pressure transducers were used to quantify water discharge at all subsurface drainage fields, while Crump weir, modified Crump weir, and combined profile weir and pressure transducers were used at small catchment scale of the study sites. The time frame of this study is from 1995 to 2018. Water samples were collected on monthly basis and analysed for $\mathrm{TN}$ and $\mathrm{NO}_{3}-\mathrm{N}$ concentrations in an accredited laboratory.

\section{Methodology}

Three subsurface drainage field and three small catchments with long-term data are used to determine TN and NO3-N losses and concentrations.

Previous study indicates that there is a positive correlation between annual precipitation and discharge for the subsurface drainage fields at the Berze, Mellupite, and Vienziemite study sites with correlation coefficients of $0.75,0.82$, and 0.53 , respectively [5]. Therefore, annual mean water discharge varies in different study sites according to meteorological and hydrological differences. For example, Vienziemite monitoring site is located in a region with higher precipitation than other two study sites.

One of the commonly used tools for detecting changes in meteorological and hydrologic time series is trend analysis [8], [10]. A number of statistical tests are used to assess the significance of trends in time series, a statistical trend analysis in this study was carried out based on the Mann-Kendall test. The Mann-Kendall test is a widely used non-parametric statistical method used to detect monotone trends in time series of water quality data [9], [10], [12]. In this study water discharge, $\mathrm{TN}$ and $\mathrm{NO}_{3}-\mathrm{N}$ of each study site were analysed for trends. The Mann-Kendall tests measure the significance of changes in the central tendency (median) of time-series data [11], [13].

\section{RESULTS AND DISCUSSION}

Long-term mean annual losses and concentrations of $\mathrm{TN}$ and $\mathrm{NO}_{3}-\mathrm{N}$ differ among study sites. Overall, range in $\mathrm{TN}$ losses varies from 4.46 to $18.74 \mathrm{~kg} \mathrm{ha}^{-1}$ and $\mathrm{NO}_{3}-\mathrm{N}$ from 2.40 to $17.28 \mathrm{~kg} \mathrm{ha}^{-1}$ and concentrations for $\mathrm{TN}$ differ from 1.42 to $10.73 \mathrm{mg} \mathrm{L}^{-1}$ and $\mathrm{NO}_{3}-\mathrm{N}$ from 0.66 to $9.97 \mathrm{mg} \mathrm{L}^{-1}$ (Table 1 ).

TABLE 1. LONG-TERm (1995-2018) ANNUAL MEAN WATER Discharge AND TOTAL Nitrogen AND NiTRATE $\left(\mathrm{NO}_{3}\right.$-N) CONCENTRATIONS AND LOSSES FROM AGRICULTURAL LAND

\begin{tabular}{llccccc}
\hline & & $\mathrm{Q}, \mathrm{mm}$ & $\mathrm{TN}, \mathrm{kg} \mathrm{ha}^{-1}$ & $\mathrm{NO}_{3}-\mathrm{N}, \mathrm{kg} \mathrm{ha}^{-1}$ & $\mathrm{TN}, \mathrm{mg} \mathrm{L}^{-1}$ & $\mathrm{NO}_{3}-\mathrm{N}, \mathrm{mg} \mathrm{L}^{-1}$ \\
\hline \multirow{2}{*}{ Berze } & subsurface drainage field & 180.1 & 18.74 & 17.28 & 10.73 & 9.97 \\
& small catchment & 170.1 & 15.21 & 13.01 & 8.12 & 7.19 \\
\multirow{2}{*}{ Mellupite } & subsurface drainage field & 247.3 & 17.72 & 16.04 & 7.07 & 6.55 \\
& small catchment & 247.5 & 11.24 & 8.76 & 3.69 & 2.76 \\
\multirow{2}{*}{ Vienziemite } & subsurface drainage field & 269.6 & 4.46 & 2.40 & 1.42 & 0.66 \\
& small catchment & 276.8 & 5.31 & 2.88 & 1.70 & 0.82 \\
\hline
\end{tabular}

TN losses varied in different monitoring sites. The Berze and Mellupite monitoring sites show up to $25 \%$ higher TN losses in subsurface drainage field scale when compared with 
small catchments and up to $15 \%$ differences among both scales of measurements at the Vienziemite monitoring site.

Common trends are determined for the Berze and Mellupite monitoring sites where TN and $\mathrm{NO}_{3}-\mathrm{N}$ losses are higher in subsurface drainage field level than in small catchment level. Although, in the Vienziemite monitoring site situation is opposite $-\mathrm{TN}$ and $\mathrm{NO}_{3}-\mathrm{N}$ losses in subsurface drainage field are lower than at the small catchment.

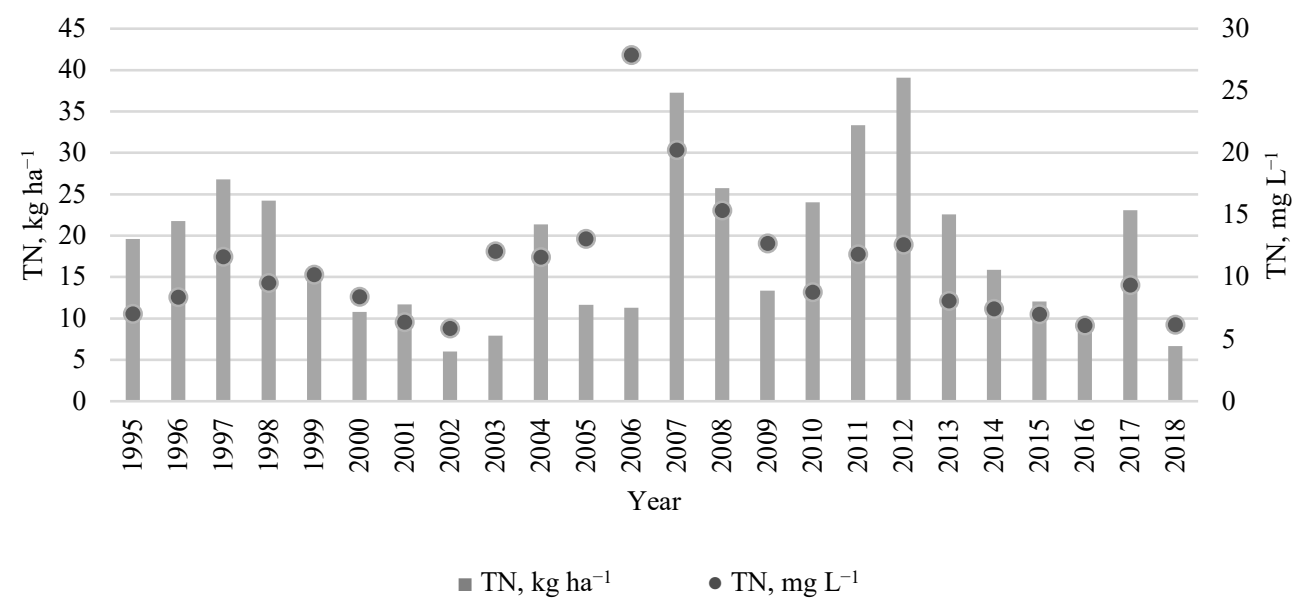

Fig. 2. Annual losses $\left(\mathrm{kg} \mathrm{ha}^{-1}\right)$ and concentrations $\left(\mathrm{mg} \mathrm{L}^{-1}\right)$ of total nitrogen $(\mathrm{TN})$ in the Berze subsurface drainage field.

Overall, two separate trends appear in TN concentrations at the Berze subsurface drainage field scale - upward trend from 1995 until 2006 and downward trend onwards until 2018 (Fig. 2). In 2006, meteorological conditions differed from other study years with high air temperatures and decreased water discharge, which resulted in high TN concentration and relatively low TN losses.

Similar to the Berze subsurface drainage study site - an upward trend in Berze small catchment is observed until 2009 and downward trend until 2018 (Fig. 3). At the Berze small catchment scale periodically, for example, from 2006 to 2010, TN concentrations are high when compared with respective TN losses. Previous studies showed [11], [13] that TN concentration and loss ratio is strongly affected by hydrological and meteorological conditions in a particular time period. 


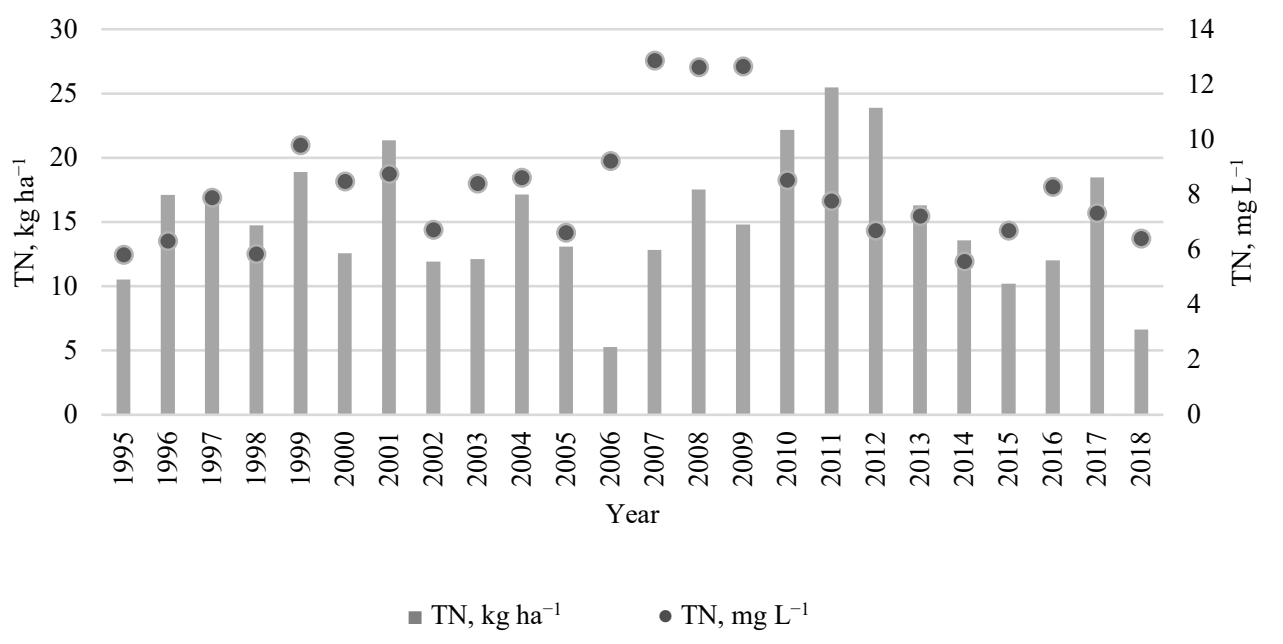

Fig. 3. Annual losses $\left(\mathrm{kg} \mathrm{ha}^{-1}\right)$ and concentrations $\left(\mathrm{mg} \mathrm{L}^{-1}\right)$ of total nitrogen (TN) in the Berze small catchment.

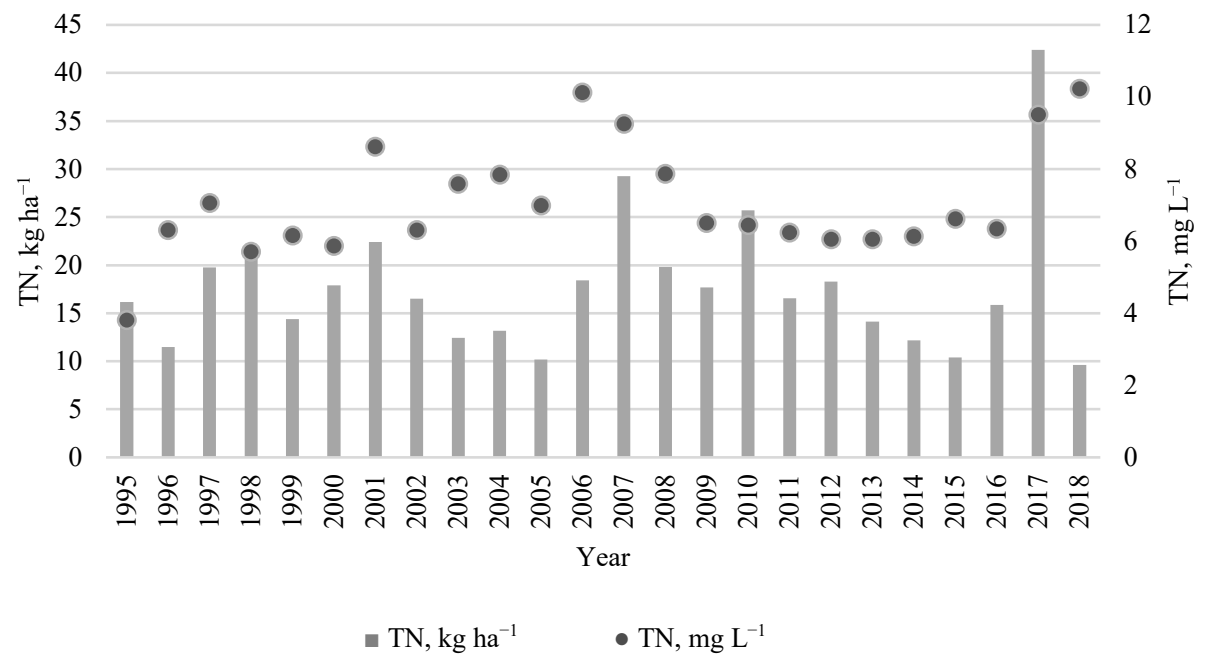

Fig. 4. Annual losses $\left(\mathrm{kg} \mathrm{ha}^{-1}\right)$ and concentrations $\left(\mathrm{mg} \mathrm{L}^{-1}\right)$ of total nitrogen (TN) in the Mellupite subsurface drainage field.

In Mellupite subsurface drainage field scale, TN concentrations are higher than in small catchment scale, it can be concluded that in this case the drainage field scale is more sensitive to $\mathrm{TN}$ concentration levels than the catchment scale, although average water discharge levels do not differ. 


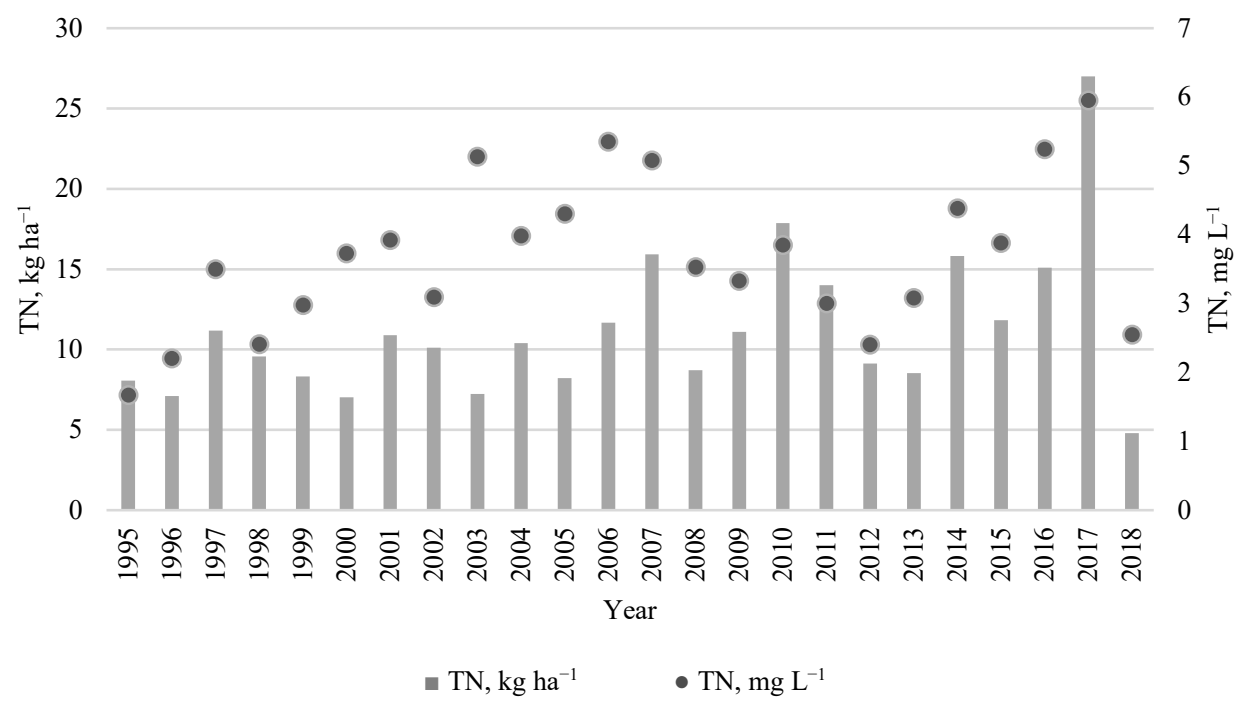

Fig. 5. Annual losses $\left(\mathrm{kg} \mathrm{ha}^{-1}\right)$ and concentrations $\left(\mathrm{mg} \mathrm{L}^{-1}\right)$ of total nitrogen $(\mathrm{TN})$ in the Mellupite small catchment.

It can be detected that there are similar tendencies between TN losses and concentrations at both subsurface drainage field and small catchment scales for the Berze and Mellupite study sites - upward trend until 2006-2009 and downward trend until 2018. It is of note that in 2008 the methodology for development of crop fertilization plans was developed by the Ministry of Agriculture aiming to ensure economically beneficial yield, as well as to ensure the quality of products, maintain soil fertility and eliminate nutrient losses and limit environmental pollution.

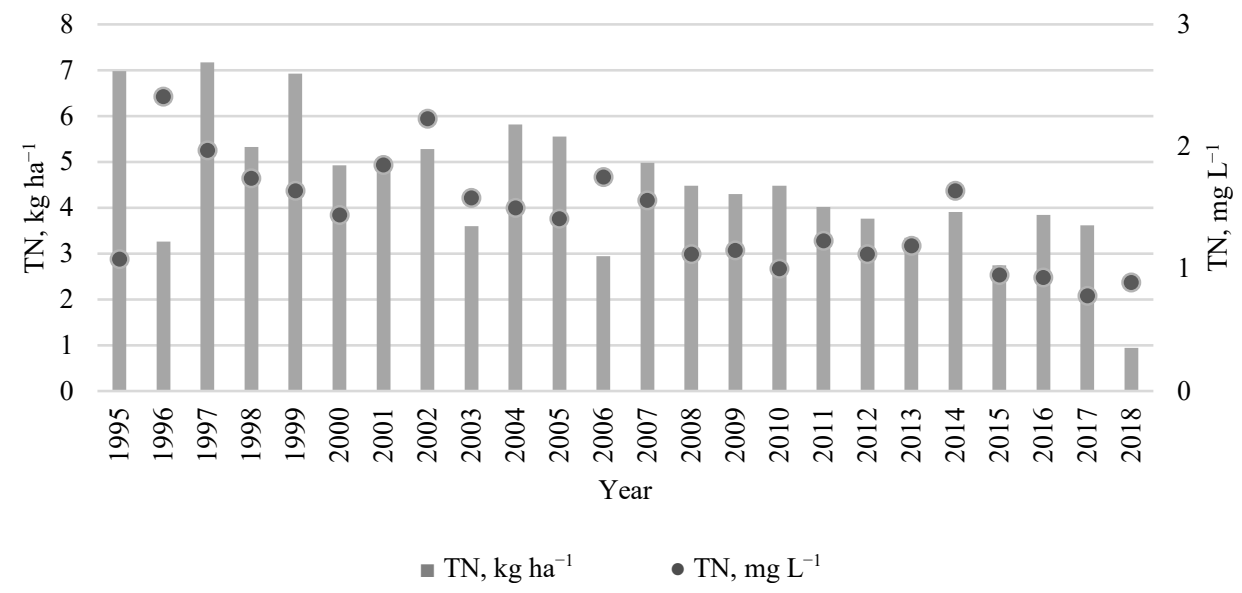

Fig. 6. Annual losses $\left(\mathrm{kg} \mathrm{ha}^{-1}\right)$ and concentrations $\left(\mathrm{mg} \mathrm{L}^{-1}\right)$ of total nitrogen $(\mathrm{TN})$ in the Vienziemite subsurface drainage field. 
$2020 / 24$

Vienziemite monitoring site has an overall downward trend in TN loss and concentrations during the study period and also the lowest TN losses and concentrations both in subsurface drainage field and small catchment scale. This can be explained by low input agricultural activities in the surrounding area and local meteorological conditions - high precipitation level and low temperatures.

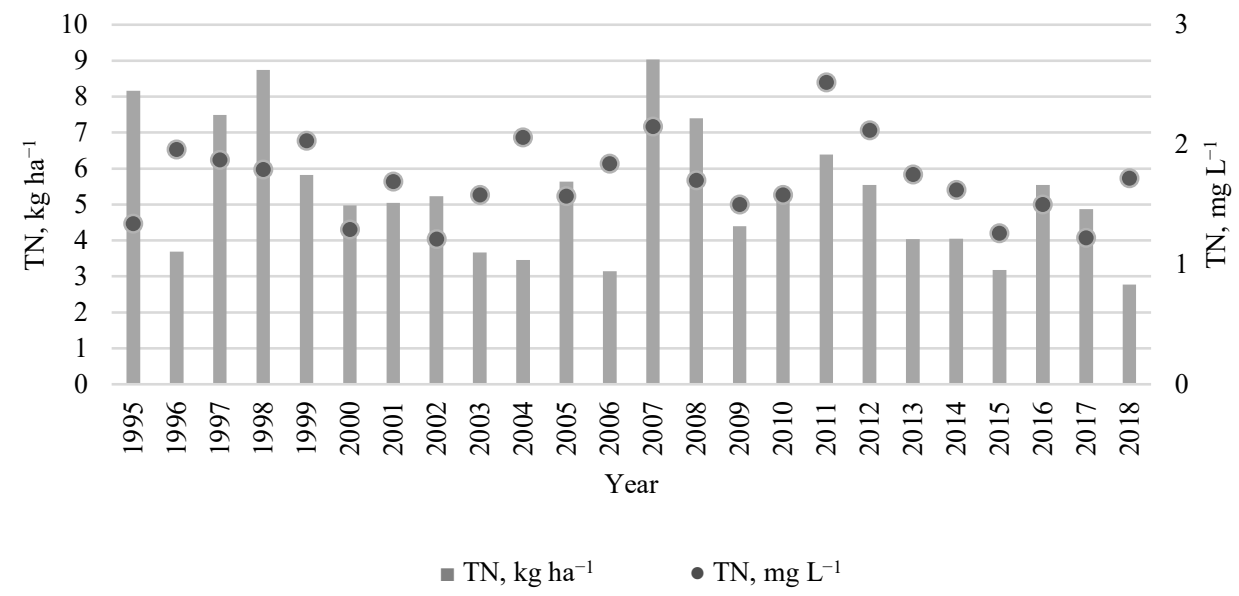

Fig. 7. Annual losses $\left(\mathrm{kg} \mathrm{ha}^{-1}\right)$ and concentrations $\left(\mathrm{mg} \mathrm{L}^{-1}\right)$ of total nitrogen $(\mathrm{TN})$ in the Vienziemite small catchment.

The monitoring data indicate that in all three study sites at the catchment scale in $2018 \mathrm{TN}$ concentrations are higher than respective loss due to weather conditions as 2018 was a year of draught, in the first half of the year the precipitation amount was only $42 \%$ from long-term average.

Table 2. Statistically Significant (Mann-Kendall Test) Trends of Water Discharge AND DIFFERENT NitROGEN FORMS IN AGRICULTURAL RUN-OFF

\begin{tabular}{lllllll}
\hline \multirow{2}{*}{ Study site } & \multirow{2}{*}{$\mathrm{Q}, \mathrm{mm}$} & \multicolumn{2}{c}{ MK-stat, TN } & \multicolumn{2}{c}{ MK-stat, $\mathrm{NO}_{3}$-N } \\
\cline { 4 - 8 } & & & $\begin{array}{l}\text { Losses } \\
\mathrm{kg} \mathrm{ha}^{-1}\end{array}$ & $\begin{array}{l}\text { Concentrations } \\
\mathrm{mg} \mathrm{L}^{-1}\end{array}$ & $\begin{array}{l}\text { Losses } \\
\mathrm{kg} \mathrm{ha}^{-1}\end{array}$ & $\begin{array}{l}\text { Concentrations } \\
\mathrm{mg} \mathrm{L}^{-1}\end{array}$ \\
\hline \multirow{2}{*}{ Berze } & subsurface drainage field & $(+) 0.510$ & $(+) 0.195$ & $(-) 0.330$ & $(+) 0.170$ & $(-) 0.206$ \\
& small catchment & $(-) 0.186$ & $(-) 0.390$ & $(+) 0.237$ & $(+) 0.117$ & $(+) 0.644$ \\
\multirow{2}{*}{ Mellupite } & subsurface drainage field & $(+) 0.137$ & $(+) 0.399$ & $(+) 0.826$ & $(+) 0.555$ & $(+) 1.122$ \\
& small catchment & $(-) 0.589$ & $(+) 0.333$ & $(+) 1.422$ & $(+) 1.040$ & $(+) 1.762$ \\
\multirow{2}{*}{ Vienziemite } & subsurface drainage field & $(+) 1.635$ & $(+) 0.363$ & $(-) 3.689^{*}$ & $(-) 0.966$ & $(-) 3.469^{*}$ \\
& small catchment & $(+) 0.539$ & $(+) 0.183$ & $(-) 1.238$ & $(+) 0.435$ & $(+) 0.281$ \\
\hline
\end{tabular}

Note: the * refers to statistically significant trends, where $p<0.05$

For TN losses no statistically significant trend was detected. For TN concentrations, one statistically significant trend was detected among 6 study sites and scales of measurements and for $\mathrm{NO}_{3}-\mathrm{N}$ also one statistically significant trend both downward trends were detected for the Vienziemite subsurface drainage scale (Table 2). A relatively low number of statistically 
significant trends in study sites can be explained by water discharge pronounced variability among seasons and years.

In all three study sites, the upward trends of TN losses were detected in subsurface drainage field level and upward trends of $\mathrm{NO}_{3}-\mathrm{N}$ losses in small catchment level.

Although in the monitoring site of Vienziemite at subsurface drainage field scale TN losses indicate an upward trend, $\mathrm{NO}_{3}-\mathrm{N}$ losses showed a downward trend.

Overall, TN and $\mathrm{NO}_{3}-\mathrm{N}$ losses indicate an upward trend in 5 out of 6 monitoring sites, TN concentrations indicate an upward trend in $50 \%$ of observations, while for $\mathrm{NO}_{3}-\mathrm{N}$ in 4 out of 6 monitoring sites an upward trend was detected.
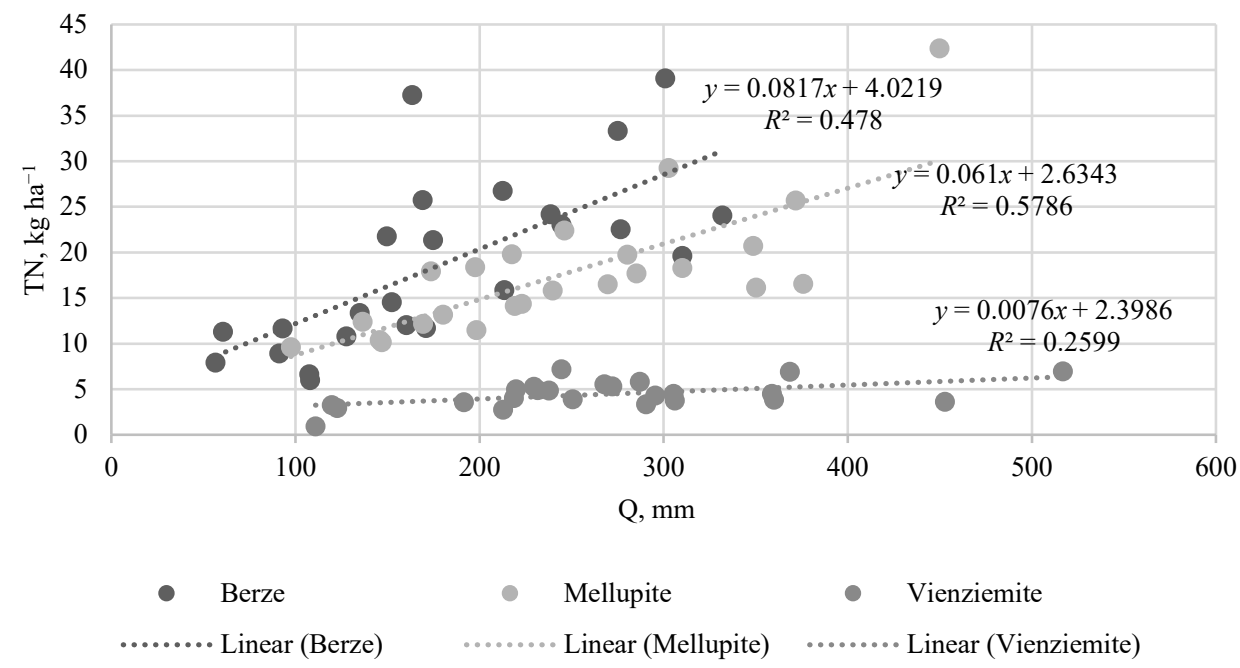

Fig. 8. Scatterplot of the TN losses $\left(\mathrm{kg} \mathrm{N} \mathrm{ha}^{-1}\right)$ vs. water discharge $(\mathrm{mm})$ in the Berze, Mellupite and Vienziemite subsurface drainage field level.

$R$-squared value, which represents the proportion of the variance for a dependent variable, for TN losses and water discharge at the subsurface drainage scale in all study sites are positive and differ from 0.26 to 0.58 . Although statistically the relationship between TN losses and discharge can be considered as moderate, these values indicate that higher TN losses can be expected if discharge increases. It remains unclear what factors affect the slope of linear relationships. The higher slope in linear relationships between TN losses and discharge is detected for the Berze site, where intensive agricultural practices are applied and soil texture is silty clay loam, the slope of relationship decreases for the Mellupite site, where moderate intensity practices are used and soil texture is loam. For the Vienziemite site the slope of relationship is close to zero indicating a minor effect of discharge on TN losses. 


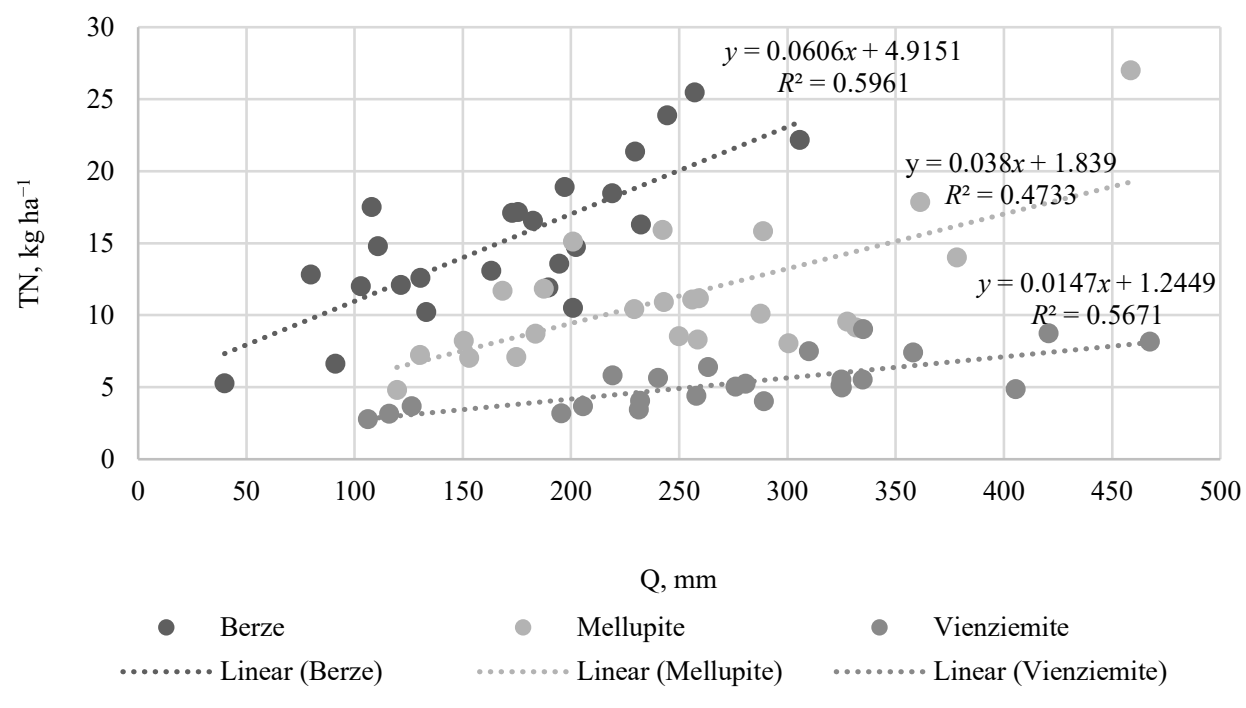

Fig. 9. Scatterplot of the TN losses $\left(\mathrm{kg} \mathrm{N} \mathrm{ha}^{-1}\right)$ vs. water discharge $(\mathrm{mm})$ in the Berze, Mellupite and Vienziemite small catchment level.

Correlation between TN losses and water discharge in the small catchment level are higher than at the subsurface drainage field scale and varies from 0.47 to 0.60 , which shows more pronounced impact of discharge on TN losses at this scale of measurements.

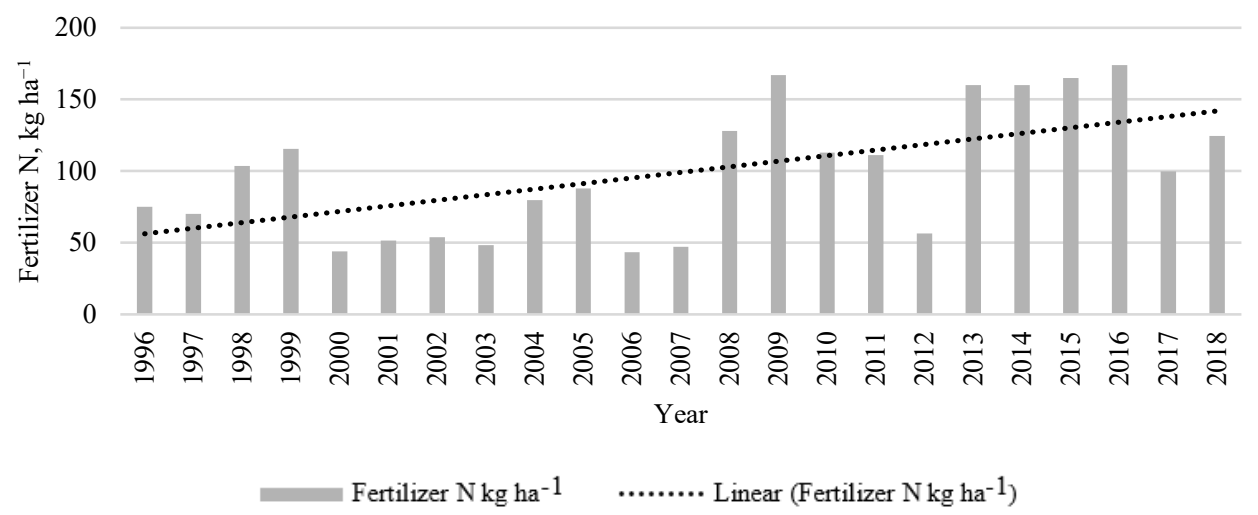

Fig. 10. Long-term (1996-2018) mean annual $\mathrm{N}\left(\mathrm{kg} \mathrm{ha}^{-1}\right)$ application rates at the Mellupite subsurface drainage field.

Water discharge, TN concentration, TN losses has increasing trend at the Mellupite subsurface drainage field scale (Table 2), also mineral fertilizer application rates has an upward trend (Fig. 10), although there is a weak relationship between the annual mean values of $\mathrm{N}$ application rates and $\mathrm{TN}$ concentrations.

The results of this study (Fig. 8-10) does not reveal clear evidences that total nitrogen concentration and losses increase by fertilizer application rates and supports the results of the previous study, which states that upward trends in nitrogen losses are affected by a 
combination of factors including management activities in agricultural fields and hydrological, meteorological conditions [12], [13].

\section{CONCLUSIONS}

The study has analysed the long-term (1995-2018) water discharge, total nitrogen (TN) and nitrate-nitrogen $\left(\mathrm{NO}_{3}-\mathrm{N}\right)$ data obtained in three water quality monitoring sites in Latvia. The monitoring data indicate different levels of $\mathrm{TN}$ and $\mathrm{NO}_{3}-\mathrm{N}$ concentrations and losses at the Berze, Mellupite, and Vienziemite subsurface drainage field and small catchment scales depending on the scale of measurements, intensity of agricultural practices, and hydrological conditions. The $\mathrm{TN}$ and $\mathrm{NO}_{3}-\mathrm{N}$ losses show an upward trend in 5 out of 6 study sites, while $\mathrm{TN}$ and $\mathrm{NO}_{3}-\mathrm{N}$ concentrations represent an upward trend in 4 out of 6 study sites with a large interannual variability among all study sites and scales of measurements. The interannual variability has to be analysed in a greater detail in future studies as long-term trends are not capable to detect short term effects of factors that may have impact on $\mathrm{TN}$ and $\mathrm{NO}_{3}-\mathrm{N}$ concentrations and losses. The results of this study reveal that monitoring data should be split into shorter time periods according to predefined time periods representing the EU budget planning periods, nutrient reduction measures included in the rural development programs of individual EU countries, and changes in national legislation governing legal regulations regarding fertilizer application rates and timings. More detailed study within shorter term periods may show whether there is a need to consider changes in national legislation regarding soil and nutrient management including additional restrictions in fertilizer applications, soil tillage, and land use changes. In addition, detailed study may suggest broader implementation of water retention measures in agricultural landscape such as constructed wetlands, controlled drainage, bottom dams, sedimentations ponds, woodchip bioreactors, meandering, and twostage ditches. Overall, in the long-term period $\mathrm{TN}$ and $\mathrm{NO}_{3}-\mathrm{N}$ concentrations and losses are affected both by natural and anthropogenic factors and upward trends may lead to deterioration of surface water quality in drainage fields and catchments. Meanwhile, it as to be recognized that no study cases show higher mean annual concentrations of $\mathrm{NO}_{3}-\mathrm{N}$ as permitted by the Nitrates directive $\left(11.3 \mathrm{mg} \mathrm{L}^{-1}\right)$.

\section{REFERENCES}

[1] HELCOM Baltic Sea action plan [Online]. [Accessed 11.02.2020]. Available: https://helcom.fi/baltic-sea-action-plan/

[2] Directive 91/676/EEC of the Council of the European Communities of 12 December 1991 concerning the protection of waters against pollution caused by nitrates from agricultural sources. Official Journal of European Union 1991:L $375 / 1$.

[3] Directive 2000/60/EC of the European Parliament and of the Council of 23 October 2000 establishing a framework for Community action in the field of water policy. Official Journal of European Union 2000:L 327/1.

[4] Veinbergs A., Lagzdins A., Jansons V., Abramenko K., Sudars R. Discharge and nitrogen transfer modelling in the Berze river: A HYPE setup and calibration. Environmental and Climate Technologies 2017:19:51-64. https://doi.org/10.1515/rtuect-2017-0005

[5] Siksnane I., Lagzdins A. Assessment of Economic Losses Associated with Nitrogen Leaching in Agricultural Land in Latvia. Proceedings of the $8^{\text {th }}$ International Scientific Conference Rural Development 2017:423-427. http://doi.org/10.15544/RD.2017.204

[6] Siksnane I., Lagzdins A. Analysis of Precipitation and Runoff Conditions in Agricultural Runoff Monitoring Sites. Rural sustainability Research 2018:39(334):26-31. https://doi.org/10.2478/plua-2018-0004

[7] Geospatial information of Latvia University of Life Sciences and Technologies and State limited Liability Company "Latvian Environment, Geology and Meteorology Centre".

[8] Khaled H., Ramachandra R. A modified Mann-Kendall trend test for autocorrelated data. Journal of Hydrology 1998:204:182-196. https://doi.org/10.1016/S0022-1694(97)00125-X 
[9] Helsen D. R., Hirsch R. M. Statistical Methods in Water Resources. Studies in Environmental Science 1992:49:42-60. https://doi.org/10.1016/S0166-1116(08)71096-3

[10] Sheng Y., Chun Y. W. Applicability of prewhitening to eliminate the influence of serial correlation on the MannKendall test. Water Recourses Research 2002:38(6):4-1. https://doi.org/10.1029/2001 WR000861

[11] Yu Y. S., Zou S., Whittemore D. Non-parametric trend analysis of water quality data of rivers in Kansas. Journal of Hydrology 1993:150:61-80. https://doi.org/10.1016/0022-1694(93)90156-4

[12] Stålnacke P., et al. Temporatl trends in nitrogen concentrations and losses from agricultural catchments in the Nordic and Baltic countries. Agriculture, Ecosystems and Environment 2014:198:94-103. https://doi.org/10.1016/j.agee.2014.03.028

[13] Donohue R., et al. Trends in total phosphorus and total nitrogen concentrations of tributaries to the Swan-Canning Estuary, 1987 to 1998. Hydrological Processes 2001:15(13):2411-2434. https://doi.org/10.1002/hyp.300 